\title{
ANALISIS YURIDIS EKSEKUSI OBJEK JAMINAN FIDUSIA SETELAH PUTUSAN MAHKAMAH KONSTITUSI NO. 18/PUU-XVII/2019
}

\author{
Vincenzo Verano M Keraf \\ Program Magister Ilmu Hukum, Universitas Indonesia Jakarta Indonesia \\ E-mail: veranokeraf@gmail.com
}

\begin{abstract}
ABSTRAK
Untuk mendukung kemajuan ekonomi, perusahaan pembiayaan menyediakan pembiayaan pembiayaan atas pembelian kendaraan bermotor. Dengan dilakukannya pembiayaan, maka umumnya perusahaan pembiayaan melakukan pembebanan jaminan fidusia atas kendaraan bermotor tersebut sehingga kendaraan bermotor tersebut menjadi objek jaminan fidusia. Pembebanan objek jaminan fidusia dilakukan melalui pembuatan akta jaminan fidusia dan kemudian diterbitkannya sertifikat jaminan fidusia atas objek tersebut. Undang-Undang Nomor 42 tahun 1999 tentang Jaminan Fidusia mengatur mengenai eksekusi atas objek jaminan fidusia berdasarkan sertifikat jaminan fidusia apabila debitur melakukan tindakan wanprestasi. Umumnya dalam perjanjian pembiayaan sudah di atur peristiwa atau tindakan yang dikategorikan sebagai peristiwa atau tindakan wanprestasi, dan tentu saja perjanjian pembiayaan harus ditandatangani terlebih dahulu oleh perusahaan pembiayaan dan konsumen sehingga peristiwa atau tindakan yang dikategorikan sebagai peristiwa atau tindakan wanprestasi termasuk bagian yang disepakati. Dengan adanya putusan Putusan Mahkamah Konstitusi No. 18/PUU-XVII/2019, maka untuk menentukan suatu peristiwa atau tindakan merupakan peristiwa atau tindakan wanprestasi harus berdasarkan adanya kesepakatan diantara kreditur dan debitur. Apabila tidak ada kesepakatan, maka harus menempuh upaya hukum melalui pengadilan. Disamping itu, sertifikat fidusia tidak lagi memiliki kekuatan eksekutorial dengan perlunya kesepakatan dan/atau menempuh upaya hukum.
\end{abstract}

\section{Kata Kunci: Eksekusi, Objek Jaminan, Fidusia,}

\section{ABSTRACT}

To support economic progress, finance companies provide financing for the purchase of motor vehicles. By doing financing, finance companies generally impose a fiduciary guarantee on the motor vehicle so that the motor vehicle becomes the object of a fiduciary guarantee. The imposition of a fiduciary guarantee object is carried out through the making of a fiduciary guarantee deed and then the issuance of a fiduciary guarantee certificate for the object. Law Number 42 of 1999 concerning Fiduciary Guarantees regulates the execution of objects of fiduciary security based on a fiduciary guarantee certificate if the debtor commits an act of default. Generally, in the financing agreement, events or actions that are categorized as events or acts of default are regulated, and of course the financing agreement must be signed in advance by the financing company and consumers so that events or actions that are categorized as events or acts of default are included in the agreed part. With the decision of the Constitutional Court Decision No. 18/PUU-XVII/2019, then to determine an event or action is an event or act of default, it must be based on an agreement between the creditor and the debtor. If there is no agreement, then legal action must be taken through the courts. In addition, a fiduciary certificate no longer has executive power with the need for agreement and/or legal action.

Keywords: Execution, Object of Guarantee, Fiduciary 


\section{A. PENDAHULUAN}

Dalam rangka menjalankan fungsi sebagai penyalur dana kepada masyarakat, maka industri lembaga keuangan menjalankan usahanya memberikan pembiayaan kepada konsumen (debitur). Pemberian pembiayaan oleh lembaga keuangan, dalam hal ini perusahaan pembiayaan, pada dasarnya harus dilandasi keyakinan atas kemampuan dan kesanggupan debitur untuk melunasi utangnya mengingat pembiayaan yang diberikan oleh perusahaan pembiayaan mengandung risiko. Yang dimaksud dengan perusahaan pembiayaan dalam konteks ini adalah badan usaha yang melakukan kegiatan pembiayaan barang dan/atau jasa. ${ }^{1}$ Untuk itu, perlu dilakukannya pendaftaran atas objek pembiayaan dengan jaminan (agunan) agar memitigasi risiko tersebut, dimana jaminan fidusia merupakan salah satu jaminan kebendaan yang dikenal saat ini.

Fidusia berasal dari kata fiduciair atau fides, yang artinya kepercayaan, yaitu penyerahan hak milik atas benda secara kepercayaan sebagai jaminan (agunan) bagi pelunasan piutang kreditur. Penyerahan hak milik atas benda ini dimaksudkan hanya sebagai agunan bagi pelunasan utang tertentu, di mana memberikan kedudukan yang diutamakan kepada penerima fidusia (kreditur) terhadap kreditur lainnya. ${ }^{2}$ Pada jaman romawi, fidusia disebut juga sebagai Fiducia Cum Creditore, artinya adalah penyerahan sebagai jaminan saja bukan peralihan kepemilikan. ${ }^{3}$ Fidusia tidak ada diatur dalam Kitab Undang-undang Hukum Perdata, dan lahir dari pelaksanaan asas kebebasan berkontrak yang diatur dalam Pasal 1338 Kitab UndangUndang Hukum Perdata yang menyatakan bahwa segala sesuatu perjanjian yang dibuat adalah sah bagi para pihak yang membuatnya dan berlaku sebagai undang-undang bagi yang membuatnya. Untuk mengatasi kebutuhan masyarakat serta jaminan kepastian dan perlindungan bagi perusahaan pembiayaan menyebabkan jaminan fidusia sering digunakan dalam masyarakat.

Lebih lanjut, benda-benda yang sering dibebankan dengan jaminan fidusia merupakan benda atau alat yang penting untuk menunjang mata pencaharian sehari-hari, misalnya, kendaraan roda empat atau mobil untuk menunjang pekerjaan sebagai supir taksi atau kendaraan roda dua atau motor untuk menunjang pekerjaan sebagai ojek. Konsumen (debitur) memerlukan pembiayaan namun tetap membutuhkan objek dari pembiayaan tersebut seharihari sebagai mata pencaharian. ${ }^{4}$ Fidusia merupakan jaminan utang yang banyak dipilih oleh masyarakat karena dianggap lebih sederhana dan terasa praktis penerapannya sebab barang yang dijaminkan tidak perlu diserahkan kepada perusahaan pembiayaan (kreditur) dan tetap dikuasai oleh konsumen (debitur). Hal tersebut menguntungkan konsumen (debitur) karena barang yang dijaminkan dengan fidusia tetap dapat dimanfaatkan oleh konsumen (debitur) untuk menjalankan usahanya dan hasilnya dapat berperan dalam melancarkan pembayaran pelunasan utang. ${ }^{5}$

Undang-Undang Jaminan Fidusia Nomor 42 tahun 1999 tentang Jaminan Fidusia (selanjutnya disebut sebagai "UU Jaminan Fidusia"), dibentuk dengan tujuan untuk mengatur dan memberikan kepastian hukum bagi para pihak dalam jaminan kebendaan untuk

\footnotetext{
${ }^{1}$ Indonesia, Otoritas Jasa Keuangan, Peraturan Otoritas Jasa Keuangan tentang Penyelenggaraan Usaha Perusahaan Pembiayaan, Nomor POJK 35/POJK.05/2018 Tahun 2018, Ps. 1 angka 1.

${ }^{2}$ Rachmadi Usman, Hukum Kebendaan (Jakarta: Raja Grafindo Persada, 2011), hlm. 283.

${ }^{3}$ J. Satrio, Hukum Jaminan Hak Jaminan Kebendaan Fidusia (Bandung: PT. Citra Aditya Bakti, 2002), hlm. 64.

${ }^{4}$ Andi Prajitno, Hukum Fidusia (Surabaya: Bayumedia, 2011), hlm. 6-7.

5 Gatot Supramono, Transaksi Bisnis Saham Dan Penyelesaian Sengketa Melalui Pengadilan (Jakarta: Kencana, 2014), hlm. 85.
} 
menjaminkan benda-benda bukan tanah yang selama ini tidak bisa ditampung oleh Hipotek, Hak Tanggungan atau Gadai.

Pengertian fidusia menurut UU Jaminan Fidusia adalah "Pengalihan hak kepemilikan suatu benda atas dasar kepercayaan dengan ketentuan bahwa benda yang hak kepemilikannya dialihkan tersebut tetap dalam penguasaan pemilik benda". ${ }^{6}$ Dikatakan berdasarkan kepercayaan, karena benda yang dijadikan jaminan tersebut tetap berada di tangan atau di bawah penguasan pemilik benda, yaitu pihak yang berhutang (debitur). Dikarenakan berdasarkan kepercayaan, ada kalanya kekhawatiran penerima fidusia bahwa debitur sebagai pemberi fidusia melakukan wanprestasi sehingga dengan dibebankan jaminan fidusia memberikan perlindungan bagi penerima fidusia apabila terjadi wanprestasi.

Jaminan fidusia dilakukan dengan cara constitutum possesorium, yaitu benda yang diserahkan hak kepemilikannya tersebut kepada kreditur tetapi secara fisik masih dikuasai oleh pemberi fidusia untuk kepentingan penerima fidusia. ${ }^{7}$ Pengalihan kepemilikan secara fidusia tidak dimaksudkan sebagai hak milik secara terus-menerus tetap tujuannya adalah untuk memberikan jaminan pelunasan utang debitur kepada kreditur. ${ }^{8}$ Jaminan fidusia setelah lahirnya UU Jaminan Fidusia mengharuskan dibuat dalam bentuk akta notaril dan diberikan hak baru, yaitu berupa title eksekutorial, dimana dengan parate eksekusi yang dapat dijalankan dengan serta merta oleh kreditur tanpa melalui putusan pengadilan yang bersifat tetap serta tanpa melalui juru sita pengadilan. Untuk jaminan fidusia dapat berlaku dan mempunyai kekuatan hukum yang tetap maka akta jaminan fidusia harus didaftarkan serta diterbitkan sertifikat jaminan fidusia yang didalamnya ada irah-irah "Demi Keadilan berdasarkan Ketuhanan Yang Maha Esa", sehingga jaminan fidusia tersebut dapat dijalankan dengan serta merta dengan parate eksekusi.

Lebih lanjut, setelah dibahas mengenai fidusia dan jaminan fidusia pada penjelasan di atas, maka perlu dilihat juga terkait lahirnya objek pembiayaan yang menjadi objek jaminan fidusia. Objek pembiayaan lahir dari adanya kesepakatan diantara perusahaan pembiayaan (kreditur) dengan konsumen (debitur) atas suatu objek yang dibiayai oleh perusahaan pembiayaan dalam proses pembeliannya, dimana kesepakatan tersebut dicantumkan dalam suatu perjanjian tertulis, yang sering disebut sebagai perjanjian pembiayaan. Di dalam perjanjian pembiayaan, wajib mencantumkan objek yang menjadi objek pembiayaan, serta umumnya mencantumkan juga surat kuasa pendaftaran akta fidusia dari konsumen (debitur) kepada perusahaan pembiayaan (kreditur), serta ketentuan atas tindakan yang dikategorikan sebagai tindakan wanprestasi apabila dilakukan oleh konsumen (debitur) diatur dalam perjanjian pembiayaan.

Apabila suatu objek pembiayaan yang lahir berdasarkan perjanjian pembiayaan antara perusahaan pembiayaan (kreditur) dengan konsumen (debitur) telah dijaminkan dengan jaminan fidusia maka perusahaan pembiayaan telah menjadi penerima fidusia dan konsumen (debitur) telah menjadi pemberi fidusia. Oleh karena itu, apabila terjadi wanprestasi berdasarkan perjanjian pembiayaan, maka sejalan dengan ketentuan dalam UU Jaminan Fidusia, perusahaan pembiayaan dapat melakukan eksekusi atas objek jaminan fidusia. Meskipun konsumen (debitur) melakukan tindakan wanprestasi, maka perusahaan pembiayaan (kreditur) hanya berhak menjual secara umum barang jaminan dan hasil penjualan itu

${ }^{6}$ Indonesia, Undang-Undang Jaminan Fidusia, UU No. 42 Tahun 1999, LN No. 168 Tahun 1999, TLN No. 3889, Ps. 1 angka 1.

${ }^{7}$ Andi Prajitno, Hukum Fidusia: Problematika Yuridis Pemberlakuan UU No. 42 Tahun 1999, (Malang: Bayumedia, 2011), hlm. 30.

${ }^{8}$ Supianto, Hukum Jaminan Fidusia: Prinsip Publisitas Pada Jaminan Fidusia (Sleman: Garudhawaca, 2015), hlm. 15. 
dipergunakan untuk melunasi utangnya. ${ }^{9}$ Bahwa dalam fidusia, adanya kekuatan eksekutorial bahwa benda yang menjadi objek jaminan fidusia dapat dieksekusi apabila debitur telah wanprestasi karena tidak dapat memenuhi kewajibannya dalam membayar utang kepada kreditur.

Namun, saat ini, proses eksekusi atas objek jaminan fidusia oleh perusahaan pembiayaan (kreditur) apabila konsumen (debitur) melakukan tindakan wanprestasi berdasarkan perjanjian pembiayaan menjadi bias atau tidak jelas semenjak adanya putusan Mahkamah Konstitusi dengan nomor 18/PUU-XVII/2019 pada tanggal 6 Januari 2020. Hal ini dikarenakan Mahkamah Konstitusi memutuskan sertifikat jaminan fidusia tidak serta merta atau secara otomatis memiliki kekuatan eksekutorial. Selain itu, cidera janji dalam eksekusi perjanjian fidusia harus didasarkan pada kesepakatan kedua pihak antara debitur dan kreditur atau atas dasar upaya hukum (gugatan ke pengadilan) yang menentukan telah terjadinya cidera janji. ${ }^{10}$

\section{B. PEMBAHASAN}

\section{Penentuan Tindakan Wanprestasi Oleh Debitur Setelah Adanya Putusan Mahkamah Konstitusi No. 18/PUU-XVII/2019}

Penentuan suatu peristiwa atau tindakan merupakan peristiwa atau tindakan wanprestasi terkait dengan pembiayaan kendaraan bermotor umumnya diatur dalam perjanjian pembiayaan antara perusahaan pembiayaan dan konsumen, dimana berdasarkan perjanjian pembiayaan perusahaan pembiayaan merupakan kreditur dan konsumen merupakan debitur. Yang dimaksud dengan perjanjian pembiayaan adalah perjanjian diantara para pihak berdasarkan asas kebebasan berkontrak, dimana perusahaan pembiayaan sebagai kreditur dan konsumen sebagai debitur. ${ }^{11}$ Perjanjian pembiayaan merupakan suatu dokumen yang wajib dibuatkan dan disepakati antara perusahaan pembiayaan dan konsumen sesuai peraturan perundang-undangan yang berlaku, dimana dalam perjanjian pembiayaan wajib mencantumkan salah satu ketentuan berupa ketentuan pemberian peringatan dalam hal debitur wanprestasi dan ketentuan eksekusi objek jaminan fidusia dalam hal debitur wanprestasi. ${ }^{12}$

Dalam melihat penyusunan perjanjian pembiayaan antara perusahaan pembiayaan dengan konsumen dapat dilakukan pendekatan berdasarkan teori kebebasan berkontrak. Pendekatan berdasarkan teori kebebasan berkontrak adalah melalui pemikiran yang dipaparkan oleh Adam Smith, dimana adanya kebebasan membuat kontrak oleh para pihak, dan negara dalam hal ini tidak boleh campur tangan terhadap isi dari perjanjian. Pemikiran kebebasan berkontrak lahir pada abad 17, dimana maknanya adalah memiliki daya kerja yang sangat kuat, yang berarti kebebasannya tidak boleh dibatasi, baik rasa keadilan masyarakat maupun oleh aturan perundang-undangan. ${ }^{13}$ Tanpa adanya kesepakatan diantara para pihak yang membuat perjanjian, maka perjanjian tersebut dapat dibatalkan. Dengan adanya ketentuan-ketentuan yang diatur dalam suatu perjanjian, maka memberikan rasa keadilan bagi para pihak dan juga menjadi jelas aturan main yang berlaku bagi para pihak.

\footnotetext{
${ }^{9}$ Marulak Pardede, Penelitian hukum tentang implemetasi jaminan fidusia dalam pemberian kredit di Indonesia (Jakarta: Pengayoman, 2008), hlm. 30.

10 Aida Mardatillah, "MK Tafsirkan Cidera Janji dalam Eksekusi Jaminan Fidusia," https://www.hukumonline.com/berita/baca/lt5e13345852149/mk-tafsirkan-cidera-janji-dalam-eksekusi-jaminanfidusia?page=all, diakses pada tanggal 25 Juni 2021.

${ }^{11}$ Yuda Sebastian, "Pelaksanaan Perjanjian Pembiayaan Kendaraan Roda Empat Dengan Jaminan Fidusia Pada PT. Acc Finance Pekanbaru,” JOM Fakultas Hukum Volume III Nomor 2 (Oktober 2016), hlm. 2.

${ }^{12}$ Otoritas Jasa Keuangan, Peraturan Otoritas Jasa Keuangan, Ps. 34 ayat 1.

13 Ghansam Anand, "Prinsip Kebebasan Berkontrak Dalam Penyusunan Kontrak," Yuridika Volume 26 No. 2 (Mei-Agustus 2011), hlm. 89.
} 
Dalam melihat keabsahan suatu perjanjian pembiayaan, maka perlu dilihat syarat sahnya suatu perjanjian berdasarkan ketentuan yang tercantum dalam KUH Perdata. Pengaturan syarat sahnya perjanjian berdasarkan Pasal 1320 KUH Perdata, mengatur bahwa: ${ }^{14}$

1. Adanya kesepakatan di antara para pihak yang mengikatkan dirinya. Kesepakatan berarti ada persesuaian kehendak yang bebas antara para pihak mengenai hal-hal pokok yang diinginkan dalam perjanjian. Dalam hal ini, antara para pihak harus mempunyai kemauan yang bebas (sukarela) untuk mengikatkan diri, di mana kesepakatan itu dapat dinyatakan secara tegas maupun diam-diam. Bebas di sini artinya adalah bebas dari kekhilafan (dwaling, mistake), paksaan (dwang, dures), dan penipuan (bedrog, fraud). Secara a contrario, berdasarkan Pasal 1321 KUHPer, perjanjian menjadi tidak sah, apabila kesepakatan terjadi karena adanya unsur-unsur kekhilafan, paksaan, atau penipuan;

2. Kecakapan dari para pihak untuk membuat suatu perjanjian. Menurut Pasal 1329 KUHPer, pada dasarnya semua orang cakap dalam membuat perjanjian, kecuali ditentukan tidak cakap menurut undang-undang;

3. Mengenai suatu hal tertentu. Hal tertentu artinya adalah apa yang diperjanjikan hak-hak dan kewajiban masing-masing pihak, minimal barang dan/atau jasa yang dimaksudkan dalam perjanjian ditentukan jenisnya. Menurut pasal 1333 KUHPer, objek perjanjian tersebut harus mencakup pokok barang tertentu yang sekurang-kurangnya dapat ditentukan jenisnya. Pasal 1332 KUHPer menentukan bahwa objek perjanjian adalah barang-barang yang dapat diperdagangkan; dan

4. Suatu sebab (causa) yang halal. Sebab yang halal adalah isi perjanjian itu sendiri, yang menggambarkan tujuan yang akan dicapai oleh para pihak. Isi dari perjanjian itu tidak bertentangan dengan peraturan perundang-undangan yang berlaku, kesusilaan, maupun dengan ketertiban umum, dimana diatur dalam Pasal 1337 KUHPer.

Selain teori kebebasan kontrak dari Adam Smith, muncul teori terkait kebebasan berkontrak lainnya yang berusaha melihat posisi yang lebih adil diantara para pihak melalui pemikiran dari Jeremy Bentham (teori utilitarianism), yang intinya menyatakan bahwa hukum bertujuan untuk mewujudkan semata-mata apa yang berfaedah bagi orang sehingga memberikan keuntungan bagi para pihak. Secara umum Bentham menyatakan bahwa tidak seorangpun dapat mengetahui tentang apa yang baik untuk kepentingan dirinya, kecuali dirinya sendiri, sehingga pemerintah tidak boleh ikut campur dalam hal yang pemerintah sendiri tidak memahaminya. ${ }^{15}$ Fungsi pemerintah hanya sebagai pengawas dalam pelaksanaan hubungan perdata diantara para pihak, dalam hal ini diantara perusahaan pembiayaan dan konsumen. Pemerintah dapat campur tangan apabila suatu perjanjian yang dibuat atau disepakati melanggar peraturan perundang-undangan yang berlaku di Indonesia, dimana atas hal tersebut maka pemerintah dapat campur tangan dalam menjalankan fungsinya sebagai pengawas.

Selain kedua pemikiran tersebut, terdapat pemikiran lainnya dari Hugo de Groot (Hugo Grotius) yang menyatakan bahwa hak untuk mengadakan perjanjian adalah salah satu hak asasi manusia sebagai bagian dari hukum alam berdasarkan rasio manusia. Groot beranggapan bahwa suatu kontrak adalah suatu tindakan sukarela dari seseorang, dimana ia berjanji sesuatu kepada orang lain dengan maksud bahwa orang lain itu akan menerimanya. ${ }^{16}$

14

Shanti

Rachmadsyah,

"Hukum

Perjanjian,"

https://www.hukumonline.com/klinik/detail/ulasan/lt4c3dle98bb1bc/hukum-perjanjian/, diakses pada 21 Juni 2021.

15 Tami Rusli, "Asas Kebebasan Berkontrak Sebagai Dasar Perkembangan Perjanjian Di Indonesia," Pranata Hukum Volume 10 No. 1 (Januari 2015), hlm. 27.

${ }^{16}$ Septarina Budiwati, “Asas Kebebasan Berkontrak dalam Perspektif Pendekatan Filosofis," Prosiding Seminar Nasional (2015), hlm. 282. 
Disamping teori kebebasan berkontrak, terdapat teori lainnya, yaitu teori tujuan hukum. Teori tujuan hukum berdasarkan Gustav Radbruch, menyatakan bahwa terdapat 3 (tiga) tujuan utama dari hukum, yaitu keadilan hukum, kemanfaatan hukum, dan kepastian hukum. Sekalipun ketiganya merupakan nilai dasar hukum, namun masing-masing nilai mempunyai tuntutan yang berbeda satu dengan yang lainnya, sehingga ketiganya mempunyai potensi untuk saling bertentangan dan menyebabkan adanya ketegangan antara ketiga nilai tersebut (Spannungsverhaltnis). ${ }^{17}$ Berdasarkan teori ini, dengan adanya perjanjian pembiayaan maka memenuhi tujuan hukum itu sendiri, keadilan hukum, kemanfaatan hukum, dan kepastian hukum bagi perusahaan pembiayaan dan konsumen dan sudah jelas perjanjian pembiayaan menjadi "aturan main" bagi para pihak.

Berdasarkan teori-teori yang dijelaskan di atas dikaitkan dengan perjanjian pembiayaan yang disepakati antara perusahaan pembiayaan dan konsumen, maka pada dasarnya ketentuanketentuan yang tercantum di dalam perjanjian pembiayaan tersebut bersifat mengikat bagi para pihak, dan harus dipatuhi serta dijalankan oleh masing-masing pihak. Konteks ketentuan yang tercantum dalam perjanjian pembiayaan termasuk juga suatu peristiwa atau tindakan yang merupakan peristiwa atau tindakan wanprestasi. Oleh karena itu, apabila kreditur atau debitur melakukan salah salah peristiwa atau tindakan yang merupakan peristiwa atau tindakan wanprestasi berdasarkan Perjanjian Pembiayaan, maka seharusnya tidak dibutuhkan lagi kesepakatan antara kreditur dan debitur bahwa peristiwa atau tindakan tersebut merupakan wanprestasi atau tidak. Hal ini dikarenakan dengan pendekatan beberapa teori yang dijelaskan sebelumnya, maka pengaturan ketentuan suatu peristiwa atau tindakan merupakan wanprestasi merupakan pengaturan yang diperbolehkan sebagai bentuk kebebasan berkontrak, serta merupakan kepastian hukum bagi kreditur dan debitur, khususnya kepastian peristiwa atau tindakan apa saja yang merupakan wanprestasi dan mana yang bukan merupakan wanprestasi.

Lebih lanjut, berdasarkan UU Jaminan Fidusia, disebutkan bahwa bahwa jaminan fidusia merupakan perjanjian ikutan dari suatu perjanjian pokok yang menimbulkan kewajiban bagi para pihak untuk memenuhi suatu prestasi. ${ }^{18}$ Yang dimaksud dengan "prestasi" dalam ketentuan ini adalah memberikan sesuatu, berbuat sesuatu, atau tidak berbuat sesuatu, yang dapat dinilai dengan uang. Dikarenakan jaminan fidusia merupakan perjanjian ikutan atau perjanjian accesoir, berarti ada perjanjian pokok yang menjadi induk dari perjanjian jaminan fidusia. Sebagai contoh, jika perjanjian pokoknya adalah perjanjian pembiayaan, maka jaminan fidusia bisa menjadi perjanjian ikutan dari perjanjian pembiayaan tersebut. Oleh karena itu, apabila konsumen (debitur) melakukan tindakan wanprestasi berdasarkan perjanjian pembiayaan maka perusahaan pembiayaan (kreditur) dapat melaksanakan haknya berdasarkan UU Jaminan Fidusia dengan melakukan eksekusi apabila objek atas perjanjian pembiayaan telah dijaminkan dengan jaminan fidusia, dimana dibuktikan dengan terbitnya sertifikat jaminan fidusia atas objek tersebut.

Namun, pada tanggal 6 Januari 2020, Mahkamah Konstitusi mengeluarkan Putusan Mahkamah Konstitusi No. 18/PUU-XVII/2019 (selanjutnya disebut sebagai "Putusan MK") sehubungan dengan adanya pengajuan uji materiil atas UU Jaminan Fidusia, khususnya terkait eksekusi mengenai objek jaminan fidusia. Amar dari Putusan MK yang telah dibacakan oleh Majelis Hakim, adalah sebagai berikut: ${ }^{19}$

1. Menyatakan Pasal 15 ayat (2) UU Jaminan Fidusia bertentangan dengan UUD 1945 dan tidak mempunyai kekuatan hukum mengikat sepanjang tidak dimaknai "terhadap jaminan

${ }^{17}$ Supriyono, “Terciptanya Rasa Keadilan, Kepastian Dan Kemanfaatan Dalam Kehidupan Masyarakat," Jurnal Ilmiah FENOMENA Volume XIV Nomor 2 (November 2016), hlm. 1573.

${ }^{18}$ Indonesia, Undang-Undang Jaminan Fidusia, Ps. 4.

${ }^{19}$ Mahkamah Konstitusi Republik Indonesia, Putusan No. 18/PUU-XVII/2019, hlm. 125-126. 
fidusia yang tidak ada kesepakatan tentang cidera janji (wanprestasi) dan debitur keberatan menyerahkan secara sukarela objek yang menjadi jaminan fidusia, maka segala mekanisme dan prosedur hukum dalam pelaksanaan eksekusi Sertifikat Jaminan Fidusia harus dilakukan dan berlaku sama dengan pelaksanaan eksekusi putusan pengadilan yang telah berkekuatan hukum tetap";

2. Menyatakan Pasal 15 ayat (2) UU Jaminan Fidusia sepanjang frasa "kekuatan eksekutorial" bertentangan dengan UUD 1945 dan tidak mempunyai kekuatan hukum mengikat sepanjang tidak dimaknai "terhadap jaminan fidusia yang tidak ada kesepakatan tentang cidera janji dan debitur keberatan menyerahkan secara sukarela objek yang menjadi jaminan fidusia, maka segala mekanisme dan prosedur hukum dalam pelaksanaan eksekusi Sertifikat Jaminan Fidusia harus dilakukan dan berlaku sama dengan pelaksanaan eksekusi putusan pengadilan yang telah berkekuatan hukum tetap"; dan

3. Menyatakan Pasal 15 ayat (3) UU Jaminan Fidusia bertentangan dengan UUD 1945 dan tidak mempunyai kekuatan hukum mengikat sepanjang tidak dimaknai bahwa "adanya cidera janji tidak ditentukan secara sepihak oleh kreditur melainkan atas dasar kesepakatan antara kreditur dengan debitur atau atas dasar upaya hukum yang menentukan telah terjadinya cidera janji”".

Dengan adanya Putusan MK, maka membuat kepastian dan/atau perlindungan hukum bagi perusahaan pembiayaan (kreditur) menjadi bias karena seringkali debitur menolak menyepakati apabila kreditur menyatakan konsumen (debitur) telah melakukan peristiwa atau tindakan wanprestasi. Padahal peristiwa atau tindakan wanprestasi sudah diatur dan disepakati bersama oleh perusahaan pembiayaan (kreditur) dan konsumen (debitur) melalui penandatangan perjanjian pembiayaan. Penentuan wanprestasi sejak awal melalui perjanjian pembiayaan yang ditandatangani memberikan kejelasan bagi para pihak karena salah satu pihak tidak bisa menyatakan pihak lainnya wanprestasi secara tidak berdasar atau tidak jelas.

Dengan sudah adanya ketentuan peristiwa atau tindakan wanprestasi dalam perjanjian pembiayaan, membuat pihak yang dirugikan tidak memerlukan kesepakatan dikemudian hari dari pihak yang melakukan wanprestasi karena peristiwa atau tindakan wanprestasi sudah ada sejak awal. Disamping itu, untuk menentukan suatu pihak melakukan wanprestasi disertai dengan pemberian surat peringatan dari perusahaan pembiayaan (kreditur), sehingga konsumen (debitur) memiliki kesempatan untuk memastikan benar atau tidaknya telah dilakukan wanprestasi. Apabila tidak ada bantahan dari konsumen (debitur), maka dapat dinyatakan bahwa konsumen (debitur) mengakui melakukan peristiwa atau tindakan wanprestasi.

Oleh karena itu, dengan telah ditandatanganinya perjanjian pembiayaan oleh para pihak, dimana telah ditentukan peristiwa atau tindakan yang dikategorikan sebagai peristiwa atau tindakan wanprestasi, termasuk pemberian surat peringatan apabila konsumen (debitur) melakukan peristiwa atau tindakan wanprestasi, sudah cukup menjadi dasar menyatakan konsumen (debitur) melakukan peristiwa atau tindakan wanprestasi, tidak perlu adanya kesepakatan kembali antara perusahaan pembiayaan (konsumen) dan konsumen (debitur). Hal ini karena dengan ditandatanganinya perjanjian pembiayaan, maka perjanjian tersebut menjadi aturan bagi para pihak yang menandatanganinya.

\section{Keberlakuan Sertifikat Fidusia Dalam Eksekusi Objek Jaminan Fidusia Setelah Adanya Putusan Mahkamah Konstitusi No. 18/PUU-XVII/2019?}

Sebelum kita masuk ke eksekusi objek jaminan fidusia, sedikit dibahas terkait wanprestasi, dimana wanprestasi itu sendiri memberikan dampak atau akibat hukum kepada pihak yang melakukannya dan menimbulkan konsekuensi terhadap hak dari pihak yang telah dirugikan untuk dapat menuntut pihak yang melakukan wanprestasi agar dapat memberi ganti rugi, sehingga tidak ada 1 (satu) pihak pun yang dirugikan akibat wanprestasi. Dengan 
terjadinya wanprestasi, maka salah satu pihak pasti akan mengambil suatu tindakan agar kerugian yang dialaminya bisa diganti atau diperbaiki. Salah satu bentuk penggantian atau perbaikan atas kerugian akibat suatu tindakan atau peristiwa wanprestasi yang terjadi adalah dengan melakukan eksekusi objek jaminan fidusia.

Secara umum eksekusi merupakan pelaksanaan dari keputusan pengadilan atau akta sehingga apabila dikaitkan dengan eksekusi atas jaminan fidusia maka merupakan penyitaan dan penjualan terhadap benda yang dijadikan sebagai objek jaminan fidusia. ${ }^{20}$ Tujuan dari dilakukannya eksekusi jaminan fidusia adalah untuk penjualan atas objek jaminan fidusia sebagai pelunasan atas kewajiban konsumen (debitur) kepada perusahaan pembiayaan (kreditur) yang belum terpenuhi. Perusahaan pembiayaan (kreditur) memiliki hak untuk menagih prestasi kepada konsumen (debitur) termasuk menagih semua cicilan dan biaya biaya lainnya yang belum dilunasi oleh konsumen (debitur), serta memiliki hak untuk mengeksekusi obyek pembiayaan yang dijadikan jaminan tanpa harus mengembalikan kelebihan harga dari hasil penjualan obyek tersebut. ${ }^{21}$ Berdasarkan UU Jaminan Fidusia, maka eksekusi atas objek jaminan fidusia dilakukan berdasarkan Pasal 29 UU Jaminan Fidusia, dimana dalam pasal tersebut diatur bahwa apabila pemberi jaminan fidusia (dalam hal ini adalah konsumen/debitur) melakukan cidera janji, maka dapat dilakukannya eksekusi terhadap benda yang dijadikan objek jaminan fidusia oleh penerima fidusia (dalam hal ini adalah perusahaan pembiayaan/kreditur). Dalam pelaksanaan eksekusi jaminan fidusia terdapat 2 (dua) janji yang dilarang dalam eksekusi jaminan fidusia, yaitu ${ }^{22}$ :

a. perjanjian yang berisikan pelaksanaan eksekusi atas objek jaminan fidusia yang bertentangan dengan Pasal 29 UU Jaminan Fidusia; dan

b. perjanjian yang berisikan kewenangan bagi penerima jaminan fidusia untuk dapat memiliki benda yang dijadikan objek jaminan fidusia apabila kreditur wanprestasi atau cidera janji.

Namun, aktualnya berdasarkan Putusan MK, perusahaan pembiayaan (kreditur) tidak dapat serta merta atau secara otomatis melakukan eksekusi atas objek jaminan fidusia berdasarkan UU Jaminan Fidusia, walaupun perusahaan pembiayaan (kreditur) telah memenuhi semua ketentuan yang diatur dalam UU Jaminan Fidusia dalam hal konsumen (kreditur) melakukan tindakan wanprestasi atau cidera janji. Putusan MK menimbulkan multitafsir karena melihat dari interpretasi yang diberikan oleh Mahkamah Konstitusi maka tidak jelas maksud dari "terhadap jaminan fidusia yang tidak ada kesepakatan tentang cidera janji (wanprestasi)". Hal ini dikarenakan dalam perjanjian pembiayaan, umumnya sudah di atur terkait tindakan apa saja yang dikategorikan sebagai tindakan wanprestasi sehingga hal ini seharusnya sudah cukup bagi perusahaan pembiayaan untuk melakukan eksekusi atas objek jaminan fidusia apabila konsumen (debitur) melakukan salah satu tindakan yang diatur tersebut. Namun, yang menjadi bias adalah tindakan yang telah diatur dalam perjanjian pembiayaan tersebut sudah sesuai atau belum dengan interpretasi Mahkamah Konstitusi atas "kesepakatan tentang cidera janji (wanprestasi)".

Selain itu, terkait dengan "debitur keberatan menyerahkan secara sukarela objek yang menjadi jaminan fidusia" seharusnya sudah jelas dengan adanya ketentuan dalam UU Jaminan Fidusia, karena diatur secara jelas menyatakan bahwa "Pemberi Fidusia wajib menyerahkan Benda yang menjadi objek Jaminan Fidusia dalam rangka pelaksanaan eksekusi Jaminan

${ }^{20}$ Usman, Hukum Kebendaan, hlm. 295.

21 Ni Putu Theresa Putri Nusantara, "Eksekusi dan Pendaftaran Objek Jaminan Fidusia Berdasarkan Undang - Undang Nomor 42 Tahun 1999 Tentang Jaminan Fidusia," Kertha Semaya: Journal Ilmu Hukum, Vol. 02, No. 02 (Maret 2018), hlm. 10.

${ }^{22}$ H. Salim HS, Perkembangan Hukum Jaminan di Indonesia, (Jakarta: PT Rajagrafindo Persada, 2012), hlm. 93. 
Fidusia.", ${ }^{23}$ dimana penjelasan atas ketentuan tersebut adalah dalam hal pemberi fidusia (debitur) tidak menyerahkan benda yang menjadi objek jaminan fidusia pada waktu eksekusi dilaksanakan, maka penerima fidusia (kreditur) berhak mengambil benda yang menjadi objek jaminan fidusia dan apabila perlu dapat meminta bantuan pihak yang berwenang. Namun dengan adanya Putusan MK, maka sudah jelas ketentuan ini akan dimanfaatkan oleh konsumen (debitur) untuk menolak menyerahkan objek jaminan fidusia kepada perusahaan pembiayaan (kreditur), terutama untuk konsumen (debitur) yang memiliki itikad buruk. Dengan adanya hal ini, jelas menyulitkan posisi dari perusahaan pembiayaan (kreditur) dalam memenuhi haknya yang sebenarnya sudah diatur berdasarkan UU Jaminan Fidusia, dan dapat berdampak ke kondisi keuangan dari perusahaan pembiayaan itu sendiri, apabila tidak dapat memenuhi haknya.

Lebih lanjut, dengan adanya Putusan MK yang menyatakan bahwa "atas dasar upaya hukum yang menentukan telah terjadinya cidera janji" maka semakin menyulitkan keadaan dari perusahaan pembiayaan (kreditur) karena perusahaan pembiayaan (kreditur) harus mengajukan gugatan wanprestasi terlebih dahulu ke pengadilan untuk dapat menyatakan bahwa konsumen (debitur) telah melakukan tindakan wanprestasi. Penyelesaian sengketa wanprestasi dan eksekusi melalui pengadilan menjadi tidak efektif, dan akan menghabiskan biaya dan waktu yang banyak, serta bukan solusi dari tercapainya keadilan dari pihak debitur dan kreditur. Karena pada dasarnya perusahaan pembiayaan (kreditur) dan konsumen (debitur) harusnya menghargai perjanjian yang telah mereka buat, dalam hal ini perjanjian jaminan fidusia yang disahkan menjadi akta jaminan fidusia.

Berdasarkan penjelasan-penjelasan di atas, maka keberlakuan hak eksekutorial dari sertifikat jaminan fidusia yang dijadikan dasar bagi penerima fidusia (perusahaan pembiayaan) dalam memenuhi haknya apabila pemberi fidusia (konsumen) melakukan tindakan wanprestasi berdasarkan perjanjian pembiayaan menjadi tidak serta merta, karena dengan dipenuhinya unsur kesepakatan tindakan wanprestasi antara perusahaan pembiayaan (kreditur) dengan konsumen (debitur) melalui perjanjian pembiayaan maka sudah jelas bahwa kesepakatan wanprestasi tersebut telah terpenuhi serta perusahaan pembiayaan (kreditur) dan konsumen (debitur) harus menghargai kesepakatan tersebut. Selain itu, Pasal 30 UU Jaminan Fidusia pun sudah mengatur secara jelas bahwa konsumen (debitur) sebagai pemberi fidusia wajib memberikan objek jaminan fidusia dalam rangka pelaksanaan eksekusi atas objek jaminan fidusia, oleh karena itu, tanpa adanya penafsiran dari Putusan MK maka sudah seharusnya konsumen (debitur) menyerahkan objek tersebut sebagai bentuk kepastian hukum bagi perusahaan pembiayaan (kreditur) sebagai penerima fidusia dalam menjalankan haknya berdasarkan UU Jaminan Fidusia.

Dengan adanya Putusan MK, maka keberlakuan dari beberapa ketentuan dalam UU Jaminan Fidusia menjadi tanda tanya karena pelaksanaannya mengikuti ketentuan dari Putusan MK yang telah menafsirkan beberapa ketentuan dalam UU Jaminan Fidusia. Namun, perlu diperhatikan juga dengan telah dilakukan wanprestasi oleh konsumen (debitur) berdasarkan perjanjian pembiayaan, membuka ruang bagi perusahaan pembiayaan (kreditur) untuk melakukan eksekusi atas objek jaminan fidusia karena peristiwa atau tindakan wanprestasi secara nyata dan jelas dilakukan konsumen, dan atas peristiwa atau tindakan tersebut tidak perlu lagi ada kesepakatan tambahan karena sudah terwakili dengan adanya penandatanganan perjanjian pembiayaan di awal sebagai bentuk kesepakatan antara perusahaan pembiayaan dan konsumen.

${ }^{23}$ Indonesia, Undang-Undang Jaminan Fidusia, Ps. 30. 


\section{KESIMPULAN}

Perusahaan pembiayaan (kreditur) sebagai penerima fidusia berdasarkan UU Jaminan Fidusia dapat melaksanakan hak eksekutorial yang diberikan melalui UU Jaminan Fidusia apabila telah menjalankan ketentuan yang dilakukan ditetapkan dalam Putusan MK. Apabila perusahaan pembiayaan (kreditur) telah menjalankan hal tersebut maka tentu saja perusahaan pembiayaan (kreditur) dapat melaksanakan haknya berdasarkan UU Jaminan Fidusia. Terlepas dari hak eksekutorial yang dimiliki oleh perusahaan pembiayaan (kreditur), maka konsumen (debitur) sebagai penerima fidusia harus menjalankan juga kewajibannya berdasarkan UU Jaminan Fidusia, dimana konsumen (debitur) diwajibkan menyerahkan objek jaminan fidusia sebagai bentuk pelaksanaan eksekusi dalam UU Jaminan Fidusia.

Dengan telah ditentukannya peristiwa atau tindakan wanprestasi dalam perjanjian pembiayaan yang telah ditandatangani oleh perusahaan pembiayaan (kreditur) dengan konsumen (debitur) maka hal tersebut menunjukkan bahwa perusahaan pembiayaan (kreditur) dan konsumen (debitur) menyepakati peristiwa atau tindakan yang dimaksud sebagai peristiwa wanprestasi sejak awal. Hal ini untuk memberikan kepastian serta perlindungan hukum yang seimbang diantara perusahaan pembiayaan (kreditur) dan konsumen (debitur) sehingga apabila salah satu dari peristiwa atau tindakan wanprestasi yang diatur dalam perjanjian pembiayaan dilakukan oleh konsumen (debitur), maka secara otomatis perusahaan pembiayaan dan konsumen (debitur) menyepakati tindakan tersebut termasuk kategori peristiwa wanprestasi dan perusahaan pembiayaan (kreditur) dapat melakukan eksekusi atas objek jaminan fidusia yang berada dalam penguasaan konsumen (debitur).

Dengan telah disepakatinya sejak awal peristiwa atau tindakan wanprestasi dalam perjanjian pembiayaan, maka perusahaan pembiayaan (kreditur) berhak untuk melakukan eksekusi atas objek jaminan fidusia sebagai bentuk penggantian atau perbaikan atas kerugian yang diakibatkan oleh peristiwa atau tindakan wanprestasi. Di samping itu, ketentuan dalam UU Jaminan Fidusia sudah mengatur juga bahwa konsumen (debitur) sebagai pemberi fidusia wajib menyerahkan objek jaminan fidusia apabila melakukan tindakan wanprestasi sehingga ketentuan tersebut sudah jelas dan adil bagi para pihak. Yang menjadi kendala dalam proses eksekusi adalah tidak diakuinya peristiwa atau tindakan wanprestasi oleh konsumen (debitur), padahal sudah diberikan surat peringatan sebelumnya oleh perusahaan pembiayaan (kreditur). Hal inilah yang justru perlu ada upaya bersama dari pihak-pihak terkait untuk mencari solusi bagi konsumen (debitur) yang tidak beritikad baik, karena tindakan tersebut bisa berdampak juga ke konsumen (debitur) yang beritikad baik.

Terkait dengan Putusan MK, seharusnya yang perlu dibenahi adalah bukan terkait penentuan cidera janji atau wanprestasi dan tindakan sukarela dari konsumen (debitur) dalam menyerahkan objek jaminan fidusia. Hal ini dikarenakan ketentuan tersebut sudah jelas tanpa adanya Putusan MK sehingga yang seharusnya perlu dibenahi adalah proses atau teknis eksekusi yang dilakukan oleh perusahaan pembiayaan (kreditur) aktualnya dilapangan seperti apa, sehingga proses eksekusi yang dilakukan menjadi jelas dan tidak menimbulkan permasalahan hukum bagi perusahaan pembiayaan (kreditur) dan konsumen (debitur) di kemudian hari.

\section{DAFTAR PUSTAKA}

HS, H. Salim. Perkembangan Hukum Jaminan di Indonesia. Jakarta: PT Rajagrafindo Persada, 2012.

Pardede, Marulak. Penelitian hukum tentang implemetasi jaminan fidusia dalam pemberian kredit di Indonesia. Jakarta: Pengayoman, 2008. 
Prajitno, Andi. Hukum Fidusia: Problematika Yuridis Pemberlakuan UU No. 42 Tahun 1999. Malang: Bayumedia, 2011.

. Hukum Fidusia. Surabaya: Bayumedia, 2011.

Supramono, Gatot. Transaksi Bisnis Saham Dan Penyelesaian Sengketa Melalui Pengadilan. Jakarta: Kencana, 2014.

Satrio, J. Hukum Jaminan Hak Jaminan Kebendaan Fidusia. Bandung: PT. Citra Aditya Bakti, 2002.

Supianto. Hukum Jaminan Fidusia: Prinsip Publisitas Pada Jaminan Fidusia. Sleman: Garudhawaca, 2015.

Usman, Rachmadi. Hukum Kebendaan. Jakarta: Sinar Grafika, 2011.

Indonesia. Undang-Undang Jaminan Fidusia, UU No. 42 Tahun 1999, LN No. 168 Tahun 1999, TLN No. 3889.

, Otoritas Jasa Keuangan. Peraturan Otoritas Jasa Keuangan tentang Penyelenggaraan Usaha Perusahaan Pembiayaan. Nomor POJK No. 35/POJK.05/2018 Tahun 2018.

Mahkamah Konstitusi Republik Indonesia. Putusan No. 18/PUU-XVII/2019.

Anand, Ghansam. "Prinsip Kebebasan Berkontrak Dalam Penyusunan Kontrak." Yuridika Volume 26 No. 2 (Mei-Agustus 2011). Hlm. 89-101.

Budiwati, Septarina. "Asas Kebebasan Berkontrak dalam Perspektif Pendekatan Filosofis." Prosiding Seminar Nasional (2015). Hlm. 276-289.

Nusantara, Ni Putu Theresa Putri. "Eksekusi dan Pendaftaran Objek Jaminan Fidusia Berdasarkan Undang - Undang Nomor 42 Tahun 1999 Tentang Jaminan Fidusia." Kertha Semaya: Journal Ilmu Hukum Vol. 02, No. 02 (Maret 2018). Hlm. 10.

Rusli, Tami. "Asas Kebebasan Berkontrak Sebagai Dasar Perkembangan Perjanjian Di Indonesia." Pranata Hukum Volume 10 No. 1 (Januari 2015). Hlm. 24-36.

Sebastian, Yuda. "Pelaksanaan Perjanjian Pembiayaan Kendaraan Roda Empat Dengan Jaminan Fidusia Pada PT. Acc Finance Pekanbaru." JOM Fakultas Hukum Volume III Nomor 2 (Oktober 2016). Hlm. 1-15.

Supriyono. "Terciptanya Rasa Keadilan, Kepastian Dan Kemanfaatan Dalam Kehidupan Masyarakat." Jurnal Ilmiah FENOMENA Volume XIV Nomor 2 (November 2016). Hlm. 1567-1582.

Mardatillah, Aida. "MK Tafsirkan Cidera Janji dalam Eksekusi Jaminan Fidusia," https://www.hukumonline.com/berita/baca/lt5e13345852149/mk-tafsirkan-ciderajanji-dalam-eksekusi-jaminan-fidusia?page=all. Diakses pada tanggal 25 Juni 2021.

Rachmadsyah, Shanti. "Hukum Perjanjian." https://www.hukumonline.com/klinik/detail/ulasan/lt4c3d1e98bb1bc/hukumperjanjian/. Diakses pada 21 Juni 2021. 